\title{
Phenotype and Fertility of Intersectional Hybrids between Tetraploid Highbush Blueberry and Colchicine-treated Vaccinium
}

\section{stamineum}

\author{
Paul M. Lyrene ${ }^{1}$ \\ Horticultural Sciences Department, University of Florida, Gainesville, FL \\ 32611
}

Additional index words. blueberry breeding, deerberry, polyploidy, wide hybridization

\begin{abstract}
Several hundred hybrid seedlings were produced by pollinating flowers of tetraploid highbush blueberry cultivars with pollen from 13 plants of Vaccinium stamineum that were selected as tetraploids following colchicine treatment. The hybrids were intermediate between the parents in many characteristics. They were less vigorous than the parents, but 46 plants flowered when 1.3 years old from seed. The $F_{1}$ hybrids produced pollen abundantly, but only $30 \%$ of the microspores appeared potentially viable when viewed at $250 \mathrm{X}$. $\mathrm{F}_{1}$ flowers that were pollinated with pollen from either parent taxon or with pollen from a different $F_{1}$ hybrid produced thousands of welldeveloped seeds. The $F_{1}$ hybrids were less successful when used as male parents in backcrosses to highbush, but 4790 well-developed seeds were obtained by pollinating 3250 highbush flowers. Flowers on $F_{1}$ plants had long peduncles and pedicels, giving an open raceme. The flowers were open in the bud and had anther awns, two characteristics from $V$. stamineum. Berries on the $F_{1}$ plants had black skins, and the ripe berries of $11 F_{1}$ plants had red to purple pulp like their $V$. stamineum parent. Berries on the hybrids were juicy. They had little or no bitterness typical of $V$. stamineum, and most had a pleasing balance of sugar and acid.
\end{abstract}

Vaccinium, which includes the commercially important crops blueberries, cranberries, lingonberries, and bilberries, is a large genus, with 150 to 450 species worldwide (Luby et al., 1991). These are grouped into 35 sections (Vander Kloet, 1997). Several Vaccinium sections, including Cyanococcus, Oxycoccus, and Myrtillus, include diploid, tetraploid, and hexaploid species. Highbush blueberry cultivars are tetraploid hybrids involving Vaccinium corymbosum and several other species in section Cyanococcus.

Within section Cyanococcus, all species at a particular ploidy level can be readily hybridized in controlled crosses (Coville, 1927; Darrow and Camp, 1945; Galletta, 1975). $F_{1}$ hybrids and seedlings from backcrosses and intercrosses are normally vigorous and fully fertile. There is a strong triploid block in Vaccinium, and only a few triploid plants have been reported (Galletta, 1975; Lyrene and Sherman, 1983; Megalos and Ballington, 1988; Vorsa and Ballington, 1991). Most hybrids between diploid and tetraploid Vaccinium species are tetraploid, due to the production of functioning $2 n$ gametes by the diploid (Galletta, 1975).

With so many species and sections, the number of potential intersectional cross

Received for publication 30 Oct. 2015. Accepted for publication 2 Dec. 2015.

${ }^{1}$ Corresponding author. E-mail: lyrene@ufl.edu. combinations in Vaccinium is very large. Relatively few attempted combinations have been reported, and no hybrid seedlings were produced in some reports. Intersectional hybrids obtained by crossing diploid Vaccinium species have usually been sterile or nearly so (Ballington, 1980; Ballington, 2001; Chavez and Lyrene, 2010; Luby et al., 1991; Lyrene, 1991; Lyrene and Ballington, 1986; Ritchie, 1955a). Diploid intersectional hybrids may produce unreduced gametes, which allow them to make fertile tetraploid hybrids when crossed with tetraploid Vaccinium species or hybrids (Ballington, 1980; Brooks and Lyrene, 1998; Lyrene and Ballington, 1986; Zeldin and McCown, 1997).

Tetraploid intersectional hybrids in $\mathrm{Vac}$ cinium range from sterile to highly fertile, depending on which species are combined and on the particular hybrid plant within a cross (Lyrene, 2011; Ritchie 1955a, 1955b; Rousi, 1963; Tsuda et al., 2013).

Vaccinium stamineum (section Polycodium; common name deerberry) is a highly polymorphic species with a native range extending from southeastern Ontario, south to central Florida, west to eastern Texas, extreme eastern Oklahoma, and extreme southeastern Kansas (Vander Kloet, 1988). A few isolated populations occur in central Mexico (Vander Kloet, 1988). Although Ashe (1931) divided Polycodium into 6 sections and 21 species, most taxonomists now treat Polycodium as one highly polymorphic species (Baker, 1970; Vander Kloet, 1988). On the coastal plain of the southeastern United States, the deerberry ranges from a subshrub $0.3 \mathrm{~m}$ tall, with stems that form large, open colonies, to arborescent shrubs nearly $5.0 \mathrm{~m}$ tall (Baker, 1970). In Florida, deerberries commonly grow on infertile, coarse-textured, white sand with little water-holding capacity. Sharpe and Sherman (1971) noted that deerberries are able to produce large berries when growing in the forest on dry, sandy soils. Deerberries in Florida often share xeric sites with turkey oak (Quercus laevis), Florida rosemary (Ceratiola ericoides), garberia (Garberia heterophylla), and other drought-tolerant species. Like other Vaccinium species, deerberries grow only on soils of low $\mathrm{pH}$.

Ballington et al. (1984b) compared seedlings of 11 Vaccinium species native in the southeastern United States in a uniform garden at Castle Hayne, NC, along with four highbush cultivars and four rabbiteye cultivars. Vaccinium stamineum had larger berries, higher percentage soluble solids, and higher berry firmness than any of the 10 section Cyanococcus species in the study and higher firmness than any of the cultivars. Mean soluble solids for 25 deerberry seedlings was $13.3 \%$, compared with a range of $7.9 \%$ to $9.0 \%$ for four highbush cultivars and $7.8 \%$ to $9.8 \%$ for four rabbiteye cultivars. Vaccinium stamineum and Vaccinium elliottii seedlings had smaller stem scar diameter than all other populations except Vaccinium myrtilloides. The authors concluded that "Vaccinium stamineum is probably worthy of domestication and improvement on its own merits as a new crop." Fruit from three genotypes of $V$. stamineum grown at Jackson Springs, NC, had soluble solid content ranging from $14.7 \%$ to $16.8 \%$, which was much higher than strawberries $(6.0 \%$ to $9.7 \%)$ and blueberries $(9.0 \%$ to $10.2 \%$ ) (Wang and Ballington, 2006). Total acidity of deerberries ranged from $0.10 \%$ to $0.21 \%$, which was lower than strawberries $(0.42-0.98)$ and blueberries $(0.38-0.82)$.

Highbush blueberries develop conspicuous flower buds in autumn. These remain dormant over winter and open to make short, leafless flowering branches in the spring. By contrast, $V$. stamineum does not form conspicuous flower buds in the fall: it flowers on new leafy shoots produced in the spring.

In flowers of highbush blueberry, the stigma and style are enclosed within the corolla tube until anthesis. At anthesis, the stigma is about even with the distal edge of the corolla tube, and the distal ends of the anthers are 1 to $3 \mathrm{~mm}$ inside the end of the corolla tube. In $V$. stamineum, the corolla tube is very short. The flowers are open in the bud (Camp, 1945) and the styles are visible outside the developing corolla tube long before anthesis. At anthesis, the corollas are short, the tips of the anthers extend 2 to $3 \mathrm{~mm}$ beyond the corolla tube, and the styles extend $\approx 5 \mathrm{~mm}$ beyond the end of the corolla tube (Fig. 1).

Ballington (1995) noted that the fruit of wild $V$. stamineum is quite large for wild 


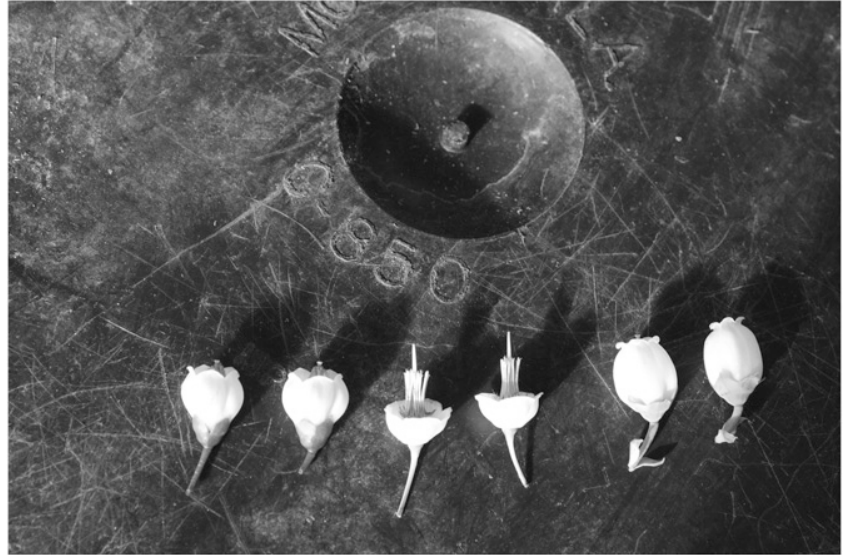

Fig. 1. Flowers of typical $\mathrm{F}_{1}$ hybrid (left), Vaccinium stamineum (center), and highbush blueberry cultivar (right).

Vaccinium, ranging from 5 to $16 \mathrm{~mm}$ in diameter, with occasional plants with fruit $19 \mathrm{~mm}$ in diameter. The color of mature deerberry fruit varies from plant to plant, ranging from greenish-white, to reddishblack, to dark purple (Ballington, 1995).

Ballinger et al. (1982) found that the anthocyanins of deerberries resemble those of Vaccinium section Oxycoccus, which includes cranberries. Ballington et al. (1988) found that the anthocyanins of deerberries, cranberries (Vaccinium oxycoccus), lingonberries (Vaccinium vitis-idaea, section Vitisidaea), and Vaccinium parvifolium (section Myrtillus) were similar. Vaccinium stamineum had only three distinct types of anthocyanins. By contrast, sparkleberry (Vaccinium arboreum, section Batodendron) had at least 12 distinct types, and its array of anthocyanins resembled highbush blueberry much more closely than did V. stamineum (Ballinger et al., 1982). Based on anthocyanin data, deerberries appeared to be less closely related to highbush blueberries than the sparkleberries.

Vaccinium stamineum fruit typically have some bitterness in the skin (Ballington, 1995), but the levels of bitterness and sweetness are quite variable. Some purple-fruited plants in the sandhill region of South Carolina, a strip of ancient beach dunes that divides the Piedmont from the Coastal Plain, were only slightly bitter, and some white-fruited forms were completely free of bitterness and had a pleasant "peary" flavor. Ballington (1995) quoted Steyermark (1963) as saying that the fruit of $V$. stamineum served cold after being cooked has a flavor suggesting cranberry and gooseberry sauce combined with grapefruit marmalade. Ballinger et al. (1981) stated that deerberry fruit resembles cranberries in fresh market and culinary qualities as well as in anthocyanin and flavonol content. Uttal (1987) described the deerberries of Virginia as "sour, bitter, or mildly sweet, the best acceptable for preserves."

Several characteristics have prevented the domestication of the deerberry as a crop plant. The plants are very difficult to propagate by stem or root cuttings, making it hard to clone superior plants for breeding or for gardening. The fruit of most plants is bitter, and from part of the geographic range, astringent. The berries on most bushes fall from the plant with pedicel attached shortly after ripening. In the forest, at the peak date of deerberry ripening, it can be hard to find plants with a large crop of mature fruit still hanging on the bush ready to harvest. Individual plants vary widely in their tendency for quick abscission of ripe berries (shattering). Ballington et al. (1984b) found nonshattering genotypes from South Carolina and Georgia, and non-shattering or delayedshattering genotypes are not uncommon in the sandhills of north Florida.

Longley (1927) and Coville (1927) found the chromosome number of $V$. stamineum to be $2 n=2 \mathrm{x}=24$. A subsequent count by McDaniel (1962) and 26 counts by Baker (1970) have all been diploid. Despite the wide range and morphological diversity of $V$. stamineum, tetraploid plants have not been reported from the wild.

Coville (1937) reported that diploid species in section Cyanococcus could be crossed with $V$. stamineum. He obtained viable hybrids between $V$. stamineum and $V$. myrtilloides, a Cyanococcus diploid (Darrow and Camp (1945). From two deerberry $\times$ blueberry crosses made in 1945, Darrow (1947) obtained 70 seeds, but he gave no details as to which blueberries were used in the crosses or whether the seeds were germinated. Meader obtained hybrids by crossing diploid lingonberry ( $V$. vitis-idaea, section Vitis-idaea) with $V$. stamineum (Ballington, 2001), but the hybrids were not vigorous (Kim Hummer, personal communication). Sharpe and Sherman (1971), from their 1970 crosses, produced what they believed based on vegetative morphology to be hybrids between section Cyanococcus and $V$. stamineum, but they were awaiting flowers and fruit to confirm the hybridity of the plants, and gave no subsequent reports.

Ballington (1980) obtained hybrid seedlings by pollinating flowers of four diploid Cyanococcus species (Vaccinium atrococcum, Vaccinium caesariense, Vaccinium darrowii, and Vaccinium tenellum) with pollen from $V$. stamineum from central South Carolina. Except for $V$. stamineum $\times V$. caesariense, in which 50 pollinated flowers gave two seedlings, the reciprocal crosses failed. Vaccinium darrowii $\times V$. stamineum diploid hybrids yielded $F_{1}$ progeny sufficiently fertile to produce $F_{2}$ and $B_{1}$ progeny (Ballington, 1980), and partially fertile diploid hybrids were also obtained from the cross $V$. tenellum $\times V$. stamineum (Ballington, 2001). In general, however, diploid hybrids between section Cyanococcus species and section Polycodium species have had very low fertility.

In 1980, three diploid Cyanococcus species (V. darrowii, Vaccinium fuscatum, and $V$. elliottii) were crossed as females with $V$. stamineum in Florida (P.M. Lyrene, unpublished data). Seedlings were obtained from each of the crosses. A few dozen of the most vigorous hybrids were maintained in a field nursery for several years, but the plants had low vigor. A few eventually flowered, but produced no berries. Diploid hybrids between $V$. darrowii and $V$. arboreum (section Batodendron), planted in the same field, were far more vigorous and produced a small amount of viable seed after open pollination in the presence of tetraploid highbush cultivars (Lyrene, 1991).

The purpose of this paper is to report the results of crosses and backcrosses involving highbush blueberry cultivars and tetraploid $V$. stamineum plants selected after colchicine treatment. The long-range goal of the project is to enable gene flow from cultivated highbush blueberries into $V$. stamineum and from $V$. stamineum into highbush. Genes from highbush may enable the production of $V$. stamineum populations that root readily from softwood cuttings, lack bitterness in the berry, and retain the ripe berries on the bush through harvest. Genes from $V$. stamineum might allow production of highbush blueberries having upland soil adaptation, open flower clusters, and berries that ripen late, and have purple flesh, increased firmness, higher soluble solids, and exotic flavors.

\section{Materials and Methods}

Open-pollinated seeds were collected from four $V$. stamineum plants growing on deep sandy soil in an open forest in southeastern Alachua County, Florida, in Aug. 2010. The plants were $2-4 \mathrm{~m}$ tall with $3-8$ major canes and were estimated to be 10 to 40 years old. The plants selected as seed sources were vigorous and upright, produced large, juicy berries, had high yields, and retained the ripe berries well on the plant. The skins of the ripe berries were black to purple and the pulp ranged in color from white/green to dark purple depending on the plant from which the berries were taken. Seeds were extracted and dried. In Nov. 2010, the dry seeds were submerged in $0.2 \%$ aqueous colchicine for $7 \mathrm{~d}$ and then planted without rinsing under intermittent mist on the surface of Canadian peat in a greenhouse at the University of Florida in Gainesville. Several thousand seedlings resulted, and in Jan. and Feb. 2011, 
$\approx 400$ were selected because they had thick hypocotyls and were transplanted to trays of peat. Three months later, 50 plants that had vegetative traits suggesting polyploidy were transplanted to pots of peat and maintained until they flowered. Pollen size was examined for each plant in early Spring 2012. Pollen was mounted in $45 \%$ acetic acid $/ 55 \%$ water and examined at $\times 250$ with a light microscope. Four plants had pollen that was conspicuously larger than the others. Additional seeds and seedlings from the same wild population were treated with colchicine in 2011 and 2012, and nine additional $V$. stamineum seedlings were found that produced categorically larger pollen. These plants were used in crosses with highbush cultivars during the three seasons of 2013 through 2015 (Table 1).

Crosses were made in a bee-proof greenhouse in Gainesville using plants growing in $10 \mathrm{~L}$ pots. The Cyanococcus plants, which were used as females, were emasculated before anthesis, and the stigmas were immediately covered with pollen brought by thumbnail from $V$. stamineum plants growing in the same greenhouse.

In 2012, two clones of $V$. darrowii (diploid Cyanococcus) were pollinated with pollen from diploid $V$. stamineum. From 649 pollinated flowers, numerous seedlings were produced and 200 were transplanted to flats of peat and were grown in a greenhouse for 4 months, after which they were transplanted to a field nursery at the University of Florida Plant Science Unit in Citra, FL. After 9 months in the field (May through January), 165 plants were identified as hybrids based on vegetative morphology. Compared with highbush seedlings, the hybrids were very weak, had yellow/bronze leaf color instead of dark green, had heavy pubescence on the petioles and stems of new shoots, and had areolate rather than reticulate leaf venation. By the end of the first growing season in the field, highbush seedlings had produced flower buds but the hybrids had not.

In 2013, intersectional (Cyanococcus $\times$ Polycodium) crosses were made at both the diploid and tetraploid level. The diploid
Cyanococcus female parents were two $V$. fuscatum plants propagated from the central Florida peninsula near Sebring, and the $V$. stamineum plants that supplied the pollen were diploids selected from the forest in southeastern Alachua County. Female parents for the tetraploid crosses were 13 highbush blueberry cultivars, and the pollen came from four $V$. stamineum plants identified as tetraploids in 2012. The number of flowers pollinated for each cross, the number of berries that matured, and the number of fully developed seeds per berry were recorded. Seeds were extracted and dried. In November of the year in which the berries were harvested, the seeds were sprinkled onto the surface of Canadian peat in an unheated greenhouse under intermittent mist. The following January and February, seedlings were transplanted to trays of Canadian peat and grown until early May in a greenhouse, when they were transplanted to a field nursery at $45 \mathrm{~cm} \times 15 \mathrm{~cm}$ spacing. About 10,000 seedlings from highbush $\times$ highbush crosses and $1000 \mathrm{~V}$. stamineum seedlings grown from seed gathered from the forest were planted in the same nursery at the same time and were used for comparisons.

Several hundred seedlings from the tetraploid intersectional crosses, which had been transplanted to the field nursery in early May, were examined in mid-Nov. 2014 to eliminate plants that did not appear to be highbush $\times V$. stamineum hybrids. About $95 \%$ of the plants appeared to be the intended hybrids. The hybrids were much less vigorous than either parent. The leaves of most hybrid plants were yellow-brown in color, in contrast to the dark green leaves of the highbush and the grey-green leaves of $V$. stamineum. The petioles, leaves and stems of the hybrids were much more pubescent than those of highbush seedlings. None of the presumed hybrids had produced visible flower buds by mid-November, whereas most highbush seedlings in the same nursery had conspicuous flower buds.

On 20 Nov. 2014, 50 of the most vigorous highbush cultivar $\times$ tetraploid $V$. stamineum seedlings were dug, potted into $10 \mathrm{~L}$ pots, and placed in a walk-in cooler without light, where they were kept for $40 \mathrm{~d}$. They were then placed in a sunny outside location for $10 \mathrm{~d}$, after which they were moved to a beeproof greenhouse with ambient light and temperature maintained between $2{ }^{\circ} \mathrm{C}$ and $27{ }^{\circ} \mathrm{C}$. During the next $40 \mathrm{~d}, 23$ more plants from the tetraploid crosses that looked like they might flower were dug from the field nursery and moved directly into the greenhouse. Between 27 Jan. and 20 Mar., 46 of the 73 putative hybrid plants in the greenhouse flowered. One of the 73 plants died, 3 were judged not to be intersectional hybrids based on flower morphology (Fig. 1) and absence of anther awns and 23 did not flower. The number of flowers produced per flowering plant ranged from 3 to 500 . Flower and inflorescence morphology were examined for each plant. The relative length of the calyx, stamens, and style were measured, and the flowers were examined at $\times 30$ for the presence of anther awns and calyx pubescence.

Potential male fertility was assessed for each plant that flowered by noting the amount of pollen that could be obtained by twirling the flower, corolla aperture down over a dark surface. The volume of pollen shed by highly fertile highbush cultivars such as Emerald and Farthing was used as a standard for "high" shed. Pollen was mounted in $45 \%$ acetic acid and examined at $\times 250$ under a light microscope. Blueberry pollen is shed in tetrads of microspores. Several hundred pollen tetrads were examined for each plant to estimate microspore fertility. The percentage of individual microspores that appeared to be well developed and potentially viable was recorded. The diameter of complete tetrads was measured for $40 \quad F_{1}$ hybrids, for 4 highbush cultivars, for 5 tetraploid $V$. stamineum clones, and for 25 diploid V. stamineum clones. Ten well-developed tetrads were measured for each plant. Some $F_{1}$ hybrids did not have enough tetrads with 4 well-developed spores to permit accurate assessment of tetrad size.

Four types of crosses (Table 2) were made in the greenhouse using $F_{1}$ plants from the

Table 1. Number of seeds or seedlings obtained during 3 years by pollinating tetraploid highbush cultivars with pollen from 13 tetraploid Vaccinium stamineum plants.

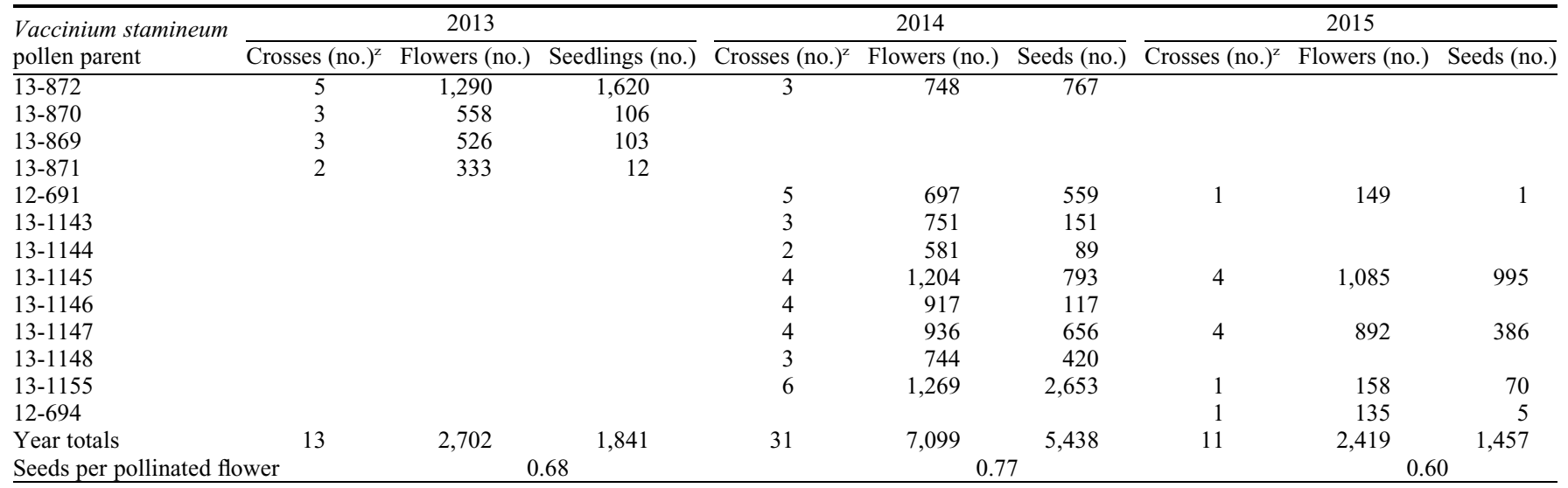

${ }^{\mathrm{z}}$ Eleven different highbush clones were used as seed parents in 2013, 20 in 2014, and 7 in 2015. 
Table 2. Results of various interspecific crosses in Vaccinium.

\begin{tabular}{|c|c|c|c|c|c|}
\hline Type of cross & Yr of cross & $\begin{array}{c}\text { Crosses } \\
\text { made }^{z} \text { (no.) }\end{array}$ & $\begin{array}{c}\text { Flowers } \\
\text { pollinated (no.) }\end{array}$ & $\begin{array}{c}\text { Seeds or } \\
\text { seedlings (no.) }\end{array}$ & $\begin{array}{l}\text { Seeds or seedlings } \\
\text { per pollinated } \\
\text { flower (no. })^{\mathrm{y}}\end{array}$ \\
\hline $\operatorname{Dar}^{\mathrm{x}} 2 \mathrm{X} \times \operatorname{Stam}^{\mathrm{x}} 2 \mathrm{X}$ & 2012 & 2 & 649 & 165 & 0.25 \\
\hline Fus $^{\mathrm{x}} 2 \mathrm{X} \times \operatorname{Stam} 2 \mathrm{X}$ & 2013 & 2 & 463 & 135 & 0.29 \\
\hline $\mathrm{HB}^{\mathrm{w}} 4 \mathrm{X} \times \operatorname{Stam} 2 \mathrm{X}$ & 2013 & 2 & 490 & 9 & 0.02 \\
\hline $\mathrm{HB} 4 \mathrm{X} \times \mathrm{Ell}^{\mathrm{xv}} 2 \mathrm{X}$ & 2014 & 14 & 4,301 & 78 & 0.02 \\
\hline $\mathrm{HB} 4 \mathrm{X} \times \operatorname{Stam} 4 \mathrm{X}^{\mathrm{u}}$ & 2015 & 11 & 2,419 & 1,457 & 0.60 \\
\hline $\mathrm{HB} \times \mathrm{F}_{1}^{\mathrm{t}}$ & 2015 & 22 & 3,250 & 4,790 & 1.47 \\
\hline $\mathrm{F}_{1} \times \mathrm{HB}$ & 2015 & 24 & 1,102 & 7,718 & 7.00 \\
\hline $\mathrm{F}_{1} \times \operatorname{Stam} 4 \mathrm{X}^{\mathrm{u}}$ & 2015 & 3 & 125 & 627 & 5.01 \\
\hline $\mathrm{F}_{1} \times \mathrm{F}_{1}$ & 2015 & 10 & 220 & 341 & 1.55 \\
\hline
\end{tabular}

${ }^{\mathrm{z}}$ Each cross involved one seed parent (listed first) and one pollen parent (listed second).

${ }^{y}$ Crosses from 2012 through 2014 based on germinated seed. Crosses of 2015 based on counts of plump, well-developed seed.

${ }^{\mathrm{x}}$ Vaccinium darrowii (Dar 2x), Vaccinium fuscatum (Fus 2x), and Vaccinium elliottii (Ell 2x) are diploid species in section Cyanococcus. Previous work by many workers has shown they are closely related to the tetraploid highbush cultivars and failure to cross readily with them is a result of the strong triploid block in Vaccinium. Vaccinium stamineum (Stam $2 \mathrm{X}$ ) were plants selected from the forest and not treated with colchicine. ${ }^{\mathrm{w}} \mathrm{HB}=$ tetraploid highbush cultivar.

"Data cited from Lyrene (2014).

${ }^{\mathrm{u}}$ Vaccinum stamineum plants selected after colchicine treatment based on large pollen size.

${ }^{\mathrm{t}} \mathrm{F}_{1}$ indicates hybrid between tetraploid highbush cultivar and tetraploid $V$. stamineum.

highbush $\times$ tetraploid $V$. stamineum crosses. Highbush flowers were pollinated with pollen from $F_{1}$ hybrids; flowers of $F_{1}$ hybrids were pollinated with pollen from one of three sources: a different $F_{1}$ hybrid, a highbush cultivar, or a tetraploid $V$. stamineum plant. The parents were selected to avoid inbreeding; every seedling had four distinct clones as grandparents. Percent fruit set, number of ripe berries harvested, and number of well-developed seeds produced by each cross were recorded.

The following berry features of the $F_{1}$ hybrids were assessed: berry weight, internal flesh color, berry detachment (easy shattering or good retention of ripe berries on the bush), whether the pedicel remained with the berry or stayed on the bush during harvest, and skin bitterness. Berry firmness was estimated subjectively by repeatedly squeezing berries between thumb and forefinger and noting the rate at which firmness declined. Berry acidity, sweetness, and aroma were judged by eating one berry from each hybrid that produced fruit. Only one berry was sampled from each plant because saving the hybrid seed was given higher priority than evaluating flavor. Degrees Brix, an estimate of percent soluble solids in the juice, was measured using a hand refractometer using fresh-squeezed juice from ripe berries for several $V$. stamineum plants growing in the forest and for several tetraploid $V$. stamineum plants and highbush blueberry cultivars growing in the greenhouse.

On 31 Aug. 2015, 20-40 leafy softwood cuttings from each of 14 of the most vigorous $\mathrm{F}_{1}$ hybrids were stuck in a peat-perlite medium under mist to determine their rooting ability. After $50 \mathrm{~d}$ (19 Oct.), the cuttings were removed from mist and placed in a sunny greenhouse. The rooted cuttings for each clone were counted $22 \mathrm{~d}$ later (10 Nov.).

\section{Results}

Intersectional crosses using pollen from diploid V. stamineum. Pollinating flowers of the diploid section Cyanococcus species, $V$. darrowii and $V$. fuscatum with pollen from diploid $V$. stamineum produced large numbers of seedlings. Seedling numbers given for these crosses in Table 2 are minimum estimates, because only a fraction of the seedlings that germinated were retained and counted. Nearly all of the seedlings that survived to be transplanted to the field nursery were very weak in the nursery compared with highbush seedlings growing nearby. One exceptional $V$. darrowii $\times V$. stamineum seedling was vigorous, and when backcrossed to a highbush cultivar, produced 100 seedlings, many of which appeared to have some $V$. stamineum features.

The two crosses of tetraploid highbush $\times$ diploid $V$. stamineum gave only 0.02 hybrid seedlings per pollinated flower along with a few dozen seedlings that resembled highbush blueberry and did not appear to be hybrids with $V$. stamineum. Several of the hybrid seedlings were quite vigorous when grown in pots of peat. They were highly variable in phenotype, some showing unusual leaf and flower forms, but they were not studied further.

Intersectional crosses using pollen from putative tetraploid $V$. stamineum. The crosses were made in 3 years, using 13 different $V$. stamineum plants, which were believed to be tetraploid, as pollen sources (Table 1) and many different highbush cultivars as seed parents. Large numbers of seedlings were obtained from most of the crosses. Seedlings from the 2013 crosses were in the field nursery long enough to allow separation, based on morphology, of the likely intersectional hybrids (more than 95\%) from seedlings from self-pollination of the highbush parent or pollination from other Cyanococcus sources. After 6 months of growth in the field, seedlings from the 2014 crosses appear to have about the same percentage of true hybrids.

Phenotype of the tetraploid hybrid seedlings in the field nursery. At the end of the first growing season in the field nursery, the 840 hybrid seedlings from the 2013 crosses were far less vigorous than seedlings of the parent species, which were planted in the same nursery at the same time. Leaves of nearly all hybrids had a bronze-yellow-green color compared with dark-green leaves on the highbush and grey-green leaves on seedlings of $V$. stamineum. Leaf petioles, leaf veins, and the stems of new vegetative growth were much more pubescent on the hybrids than on highbush seedlings. Leaf venation in the hybrids tended to be areolate, as in $V$. stamineum, rather than reticulate as in highbush blueberry. On 20 Nov., near the end of the first growing season in the field, none of the hybrids had obvious flower buds, whereas nearly all of the highbush seedlings growing nearby had conspicuous flower buds. The 1800 hybrid seedlings from the tetraploid intersectional crosses made in 2014, which were planted in a separate but nearby nursery on the same research farm, averaged much higher in vigor than the hybrids from the year before, but were still less vigorous, on average, than seedlings of either parent. Vigor was highly variable among the intersectional hybrids, with much variation both among and within $\mathrm{F}_{1}$ families.

Phenotype of 69 selected hybrid seedlings (highbush cultivar $\times$ tetraploid $V$. stamineum) in the greenhouse in 2015. Seventy-three hybrid seedlings from various highbush $x$ tetraploid $V$. stamineum crosses were selected for further study and for use as parents in backcrosses and intercrosses. These plants were selected because they were the most vigorous of the hybrid seedlings and appeared to be the most likely to flower. Of the 73 selected plants, one died in the greenhouse and three were rejected because flower and inflorescence morphology when they flowered indicated that they might not be the intended hybrids. The number of plants used to assess each phenotypic character varied. Some plants did not flower and could not be rated for flower and berry characteristics. Some plants produced too few berries to permit assessment of berry qualities, either because they produced few flowers or because the flowers had been sacrificed for pollen to make crosses.

Vegetative vigor of the potted $F_{1}$ hybrids was low as they grew, flowered, and developed fruit in the greenhouse, partly due to an infestation of azalea white mite (Eotetranychus clitus). The hybrids seemed much more susceptible to these mites than either parent species. Discoloration of the leaves and leaf drop due to mites and possibly other causes continued during most of the time between flowering and berry ripening, and probably reduced berry size and berry quality on the hybrid plants. After the crop was harvested and the mites were controlled, some of the potted hybrid plants became quite vigorous, and leaf color became healthy green on some.

Leaves on the hybrids tended to be lighter green in color than leaves of highbush. Hybrid leaf venation tended to be areolate rather than reticulate, with veins defining 
small raised islands on the upper leaf surface. Stems on new shoots were highly pubescent on most hybrid seedlings, and the leaf petioles were much more densely pubescent than on highbush. The bark pattern on 1-year-old wood was intermediate between highbush and $V$. stamineum.

The $\mathrm{F}_{1}$ hybrids did not have visible flower buds at the time they were placed in the greenhouse. However, on most of the plants, new growth flushes soon emerged that had leaves and flowers on the same raceme. In these traits the hybrids resembled $V$. stamineum. It should be noted, however, that the plants were removed from the cooler in midwinter, when short days and cool nights (as low as $5^{\circ} \mathrm{C}$ in the greenhouse on some nights) might have induced flowering even on new highbush growth flushes. Furthermore, a few of the $\mathrm{F}_{1}$ hybrid plants that had been left in the field began to form highbushtype flower buds in mid-February on wood of the previous growing season. The seedlings dug in November were only 1-year old from seed. They had grown with marked lack of vigor and may have been too juvenile to initiate flower buds in the fall. Still, the long peduncles and pedicels of the hybrids when they flowered and the presence of leaves on the peduncles was suggestive of the $V$. stamineum flowering habit (Fig. 2).

The mean diameter of well-developed pollen tetrads in diploid $V$. stamineum, estimated from 20 flowering plants, was $49 \mu \mathrm{m}$. Taking this value as $100 \%$ for comparisons, mean tetrad diameter for tetraploid V. stamineum was $125 \%$, the same as the mean for five tetraploid highbush cultivars. Mean tetrad diameter was estimated for each of $40 \mathrm{~F}_{1}$ hybrids based on 10 tetrads per plant. The median value for this population of means was $117 \%$, with values for individual plants ranging from $92 \%$ to $150 \%$. Reliability of the estimates for the $F_{1}$ plants was reduced by the fact that these plants produced very few tetrads in which all four microspores were fully developed. These tetrad sizes suggest that most, if not all of the $\mathrm{F}_{1}$ hybrids were tetraploid or near tetraploid, as would be expected from crosses between tetraploid parents.

Fertility of selected $F_{1}$ hybrid seedlings (highbush cultivar $\times$ tetraploid $V$. stamineum). Nearly all of the hybrids that flowered shed copious amounts of pollen when the flowers were twirled between thumb and index finger, corolla aperture downward. Percent viable pollen was estimated visually under a $\times 250$ microscope for 44 of the hybrid plants that flowered in the greenhouse (Table 3). Several hundred pollen tetrads were examined for each plant. One plant was estimated to have $95 \%$ good microspores, but the median plant had only $30 \%$ good microspores, and a few plants were nearly male sterile. When pollen from $F_{1}$ plants was used to pollinate flowers of highbush cultivars, numerous hybrid seedlings were obtained (Table 2), but the crosses gave far fewer seeds than would be expected from highbush $\times$ highbush crosses.
Berry set and seed production were surprisingly high when the $F_{1}$ intersectional hybrids were used as female parents in backcrosses either to highbush cultivars (7.00 good seeds per pollinated flower) or to $V$. stamineum tetraploids (average 5.01)
(Table 2; Fig. 3). When $\mathrm{F}_{1}$ hybrids were used as pollen parents to pollinate highbush cultivars or other $F_{1}$ hybrids, seed set averaged only 1.5 seeds per pollinated flower (Table 2 ). Darwin (1859) and subsequent workers (Stevenson, 1965) noted that female fertility

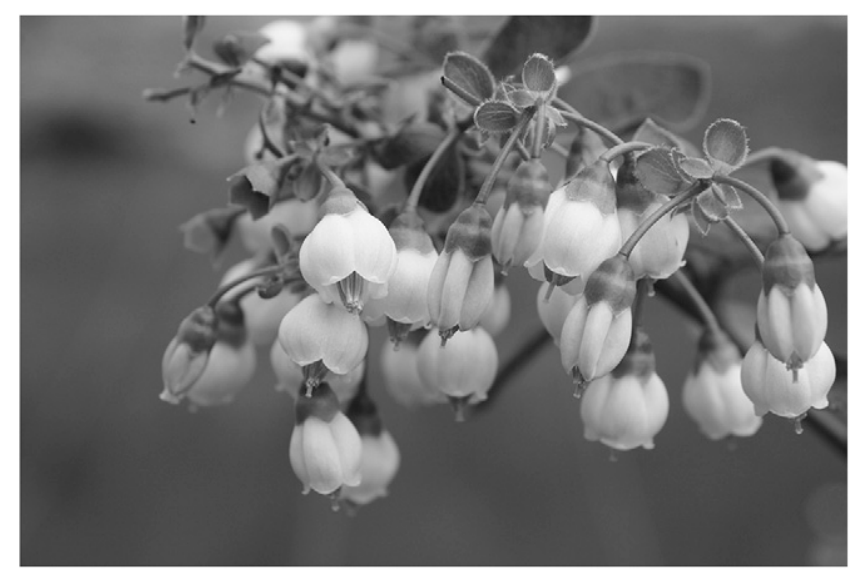

Fig. 2. Flowering raceme of an $\mathrm{F}_{1}$ hybrid between tetraploid highbush cultivar and tetraploid Vaccinium stamineum. Flowers of most $\mathrm{F}_{1}$ hybrids had long pedicels and peduncles, styles exserted from the anther tube before anthesis, and anthers and stigmas extending beyond the corolla tube at anthesis.

Table 3. Number of plants of various types having pollen in each of 11 pollen viability classes.

\begin{tabular}{|c|c|c|c|c|c|}
\hline \multirow[b]{2}{*}{ Pollen viability class ${ }^{2}(\%)$} & \multicolumn{5}{|c|}{ Number of plants in each class } \\
\hline & $\begin{array}{l}\mathrm{HB}^{\mathrm{y}} 4 \mathrm{X}^{\mathrm{x}} \\
\text { cultivars }\end{array}$ & Stam 2X & Stam $4 X$ & $\begin{array}{l}\text { Dar } 2 X \times \\
\text { Stam } 2 X\end{array}$ & $\begin{array}{l}\text { HB } 4 X \times \\
\text { Stam } 4 X\end{array}$ \\
\hline 0 to 5 & & & & 3 & 5 \\
\hline 10 & & & & 1 & 8 \\
\hline 20 & & & & 2 & 8 \\
\hline 30 & & & & & 10 \\
\hline 40 & & & & & 3 \\
\hline 50 & & & & & 8 \\
\hline 60 & & & & & 0 \\
\hline 70 & & & 1 & & 1 \\
\hline 80 & & & & & 0 \\
\hline 90 & 1 & & 1 & & \\
\hline 95 or more & 4 & 2 & 3 & & 1 \\
\hline
\end{tabular}

${ }^{2}$ Percentage of the microspores that appear fully developed when viewed at $\times 250$.

${ }^{\mathrm{y}}$ Tetraploid highbush cultivars (HB); Vaccinium darrowii, a diploid section Cyanococcus species (Dar 2X); diploid Vaccinium stamineum (Stam 2X); Vaccinium stamineum selected after colchicine treatment based on large pollen (Stam $4 \mathrm{X}$ ); Dar $2 \mathrm{X} \times \mathrm{Stam} 2 \mathrm{X}$ are $\mathrm{F}_{1}$ hybrids from this cross.

${ }^{\mathrm{x}} 4 \mathrm{X}$ and $2 \mathrm{X}$ refer to tetraploid and diploid plants.

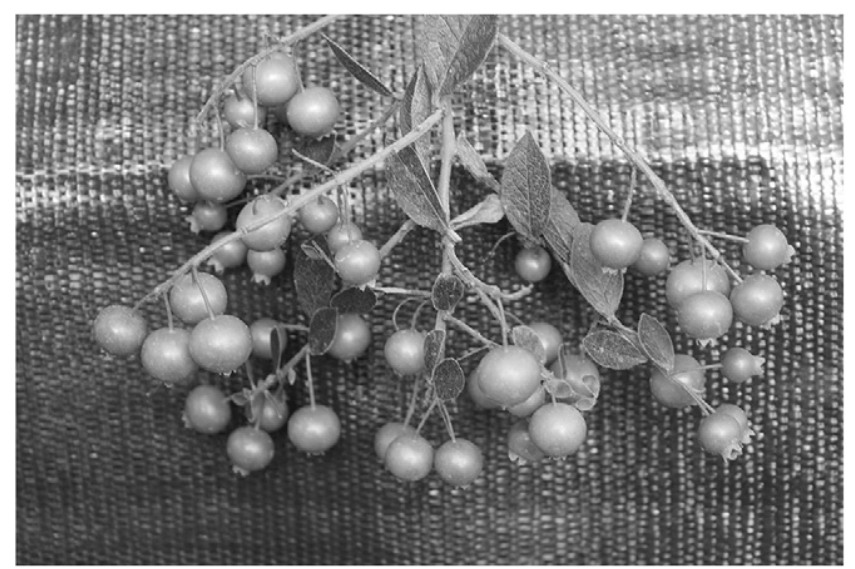

Fig. 3. Immature berries on a tetraploid $\mathrm{F}_{1}$ hybrid after pollination with pollen from a tetraploid highbush cultivar. Most $F_{1}$ hybrids had high fruit set when backcrossed to highbush cultivars or tetraploid Vaccinium stamineum. 
is normally higher than male fertility when wide hybrids are used in backcrosses.

The tetraploid $\mathrm{F}_{1}$ hybrids, when backcrossed to either parent species, produced far more seed than the original highbush $\times$ tetraploid $V$. stamineum crosses (Table 2). The same was true with highbush $\times$ tetraploid $V$. arboreum (section Batodendron) hybrids (Lyrene, 2013). This is somewhat surprising, since both parents of the initial crosses were fully fertile members of successful species, whereas one parent in the backcrosses was an intersectional hybrid, in which reduced fertility might be expected.

Other phenotypic characteristics of highbush $\times$ tetraploid $V$. stamineum $F_{1}$ hybrids brought to the greenhouse for use in crosses. The morphology of the flowers on the 46 hybrid plants that flowered in the greenhouse was generally intermediate between those of the parent taxa (Figs. 1 and 2). In all of the plants judged to be $F_{1}$ hybrids, the flowers were open in the bud as in V. stamineum, and the styles extended outside the corolla tube well before anthesis. At anthesis, the tips of the anthers were located at or near the end of the corolla tube and the stigmas extended 2 to $4 \mathrm{~mm}$ beyond the end of the corolla (Fig. 2). In highbush flowers, the distal ends of the anthers are well inside the corolla tubes and the stigmas are located at or near the proximal end of the corolla tube (Fig. 1).

Anther awns are a key character separating section Cyanococcus species (which have no or very poorly developed awns) from section Polycodium, which has large and conspicuous awns (Camp, 1945). Three of the plants that had been dug as $F_{1}$ hybrids had no awns when they flowered. Two of these lacked other clear-cut deerberry features and were probably not from the intended cross. The third plant had some features suggestive of $V$. stamineum, but was not a typical $\mathrm{F}_{1}$ hybrid and was not used in crosses. Anther awns were conspicuously present in all of the other $41 \mathrm{~F}_{1}$ plants examined for this trait. The length and thickness of the awns varied considerably from plant to plant, but the awns of the hybrids were smaller and thinner than those of $V$. stamineum. In flowers of the median plant, the awns were about half as long as the anther sac.

Berry phenotype was assessed for all $F_{1}$ plants that produced five or more berries. Berries of most $F_{1}$ plants were smaller than those of either parent. Many of the $V$. stamineum plants in the forest had large berries. Thirty of the largest berries were harvested in the forest from each of two highyielding plants on 14 July 2015 . The average weight of these selected berries was $2.01 \mathrm{~g}$ per berry (SD 0.19) for one plant and $1.75 \mathrm{~g}$ (SD 0.14) for the other. Two of the tetraploid $V$. stamineum parent clones in the greenhouse had berries that averaged almost $2 \mathrm{~g}$ after hand crosses between the two clones. Among the $F_{1}$ plants in the greenhouse, the one with the largest berries averaged $1.59 \mathrm{~g}$ per berry for the first 20 berries harvested. Only about half of the $F_{1}$ plants had average berry weight over $1.1 \mathrm{~g}$ for the first 20 berries harvested.
The smaller size of the berries on the $F_{1}$ hybrids compared with their parents probably resulted from their lower vigor and their problems with leaf mites and diseases.

Among the $\mathrm{F}_{1}$ plants evaluated for pedicel attachment, 10 had pedicels that remained on the bush when the berry was harvested, which is characteristic of most highbush individuals, while 9 had pedicels that detached with the berry, which is characteristic of $V$. stamineum, and 10 had some berries detaching in each way.

Premature berry detachment, or shattering, is an important trait as berries must be retained on the plant long enough to permit the entire crop to be harvested in two or three picks without berry loss. Little information was obtained on this trait as highest priority was given to saving all the seed obtained from the hand crosses, so most of the berries were harvested when first ripe, before they had time to shatter. Berry retention on nine $F_{1}$ plants that were evaluated for this trait varied widely. From five plants, the ripe berries detached too readily; on four others, the berries remained firmly attached.

The skin of ripe berries of all $F_{1}$ plants was black or dark purple, which was also true of most of the original $V$. stamineum plants in the forest. The berries in some of the wild $V$. stamineum were glaucous due to surface wax, but the berry surface of the $F_{1}$ plants was not glaucous or only slightly glaucous.

Flesh color of the ripe berries was of interest, because undamaged berries of highbush blueberry and all other species in section Cyanococcus have green/yellow/ white flesh, because the anthocyanins are limited to the skin. By contrast, the berries of some species in other Vaccinium sections have purple flesh and intense pigmentation throughout. Bilberry, V. myrtillus, has black to dark-purple flesh, which is considered desirable by consumers because of possible health benefits. In assessing the flesh color of the hybrids, care was taken to evaluate only berries that were not overripe and had no damage to the skin. The berries of the tetraploid $V$. stamineum parent FL13-872 have black skins and bright red flesh. Of the $F_{1}$ plants evaluated for flesh color, all 10 seedlings with $V$. stamineum FL13-872 as pollen parent had some internal pigmentation, the intensity varying from dark purple for two seedlings, bright red for two, pink for four, and greenish pink for two. Of the eight evaluated seedlings whose $V$. stamineum parent was FL13-869, seven had white/green flesh like highbush and one had purple flesh. All 14 evaluated seedlings from $V$. stamineum FL13-870 had green to white flesh. Of the tetraploid $V$. stamineum plants that were crossed with highbush, only FL13-872 and FL13-1155 had red to purple flesh; the other tetraploid $V$. stamineum clones used as parents had berries with green to white internal flesh color. The fact that flesh color varies from purple to red to yellow to green among $V$. stamineum plants in a single forest in Alachua County, FL, implies that one or a few qualitative genes control flesh pigmentation. If this is the case, internal red pigmentation from $V$. stamineum may be relatively easy to transfer into the highbush gene pool.

In the wild $V$. stamineum population from which the parents came, the berries on all plants were firm and juicy. Berries on some plants had a crisp or crunchy texture. On a few of the wild plants, the berries were large and sweet (but with bitterness ranging from slight to medium) 10 to $14 \mathrm{~d}$ before the color changed from green to purple. One-hundred purple ripe berries picked from one such plant showed no decay or softening after 3 weeks storage in a paper bag at $22{ }^{\circ} \mathrm{C}$, although the berries shriveled somewhat. Berry firmness, evaluated for 16 of the $F_{1}$ hybrids, ranged from high to very high compared with highbush blueberry cultivars such as Star, Emerald, and Farthing. Deerberries tend to have a tough skin, which can detract somewhat from their palatability but probably increases firmness and berry postharvest life.

Ballington et al. (1984b) found that deerberries grown in North Carolina from seeds obtained from wild populations in South Carolina and Florida had much higher soluble solids than the berries of highbush and rabbiteye cultivars with which they were compared. On 5 July 2012, Brix was determined for deerberries from the forest in southeastern Alachua County that was the source of $V$ stamineum parents used in this study. Brix ranged from 15.1 to 21.1 for three randomly selected plants. Another plant, selected because it had berries that seemed very firm and sweet, had a Brix of 20.6 for ripe berries picked from the bush and 24.0 for firm berries gathered from the ground beneath the bush. The Brix of frozen berries from the highbush cultivar Jewel, determined at the same time, was 15.0. Brix of ripe berries from four $V$. stamineum plant tested from the greenhouse in 2015 ranged from 16.1 to 20.0 , compared with 10.0 to 13.8 for three highbush cultivars growing in the same greenhouse.

Flavor components (bitterness, acidity, sweetness, and aromatics) were evaluated for 29 berries, one harvested from each of $29 F_{1}$ plants in the greenhouse. Only one berry per plant was sampled for flavor because saving the hybrid seeds was given priority. Flavors were probably affected by the fact that the $F_{1}$ plants were not very healthy during the fruit development period due to mites and other factors, which turned many of the leaves brownish or yellow and caused some defoliation. There was some bitterness in the skins of nearly all berries, but much less than in $V$. stamineum, and the skins of seven berries were not bitter. The berries of only one plant had detectable bitterness in the flesh. Berries from two plants were considered bland. Berries from 15 plants were considered tart, but most of these were described as "tart but pleasant." Berry flesh for 8 plants was described as "sweet." Berries from three plants were described as "aromatic." Flavor of berries from 10 plants seemed as good as or better than that of the 
highbush cultivars Star, Emerald, and Farthing. Ballington (personal communication) reported that NC2558 (1/4 V. stamineum, 1/4 $V$. darrowii, and $1 / 2$ highbush), when backcrossed to the cultivar Echota, produced a seedling population with unusually bland fruit, but when crossed with NC967, the population segregated for fruit quality. The preliminary flavor evaluations from the present study indicate that berries with good to excellent flavor should be attainable after recombining highbush and deerberry genes.

Rooting of softwood cuttings from $14 F_{1}$ intersectional hybrid plants. Percentage rooting of the softwood cuttings was $83 \%$ or higher for eight of the clones and four other clones rooted between $56 \%$ and $74 \%$. One clone, which defoliated shortly after the cuttings were stuck, rooted at $40 \%$, and one clone produced not a single rooted cutting from 20 that were stuck, even though the cuttings retained their leaves and looked healthy during $50 \mathrm{~d}$ under mist.

\section{Discussion}

Hybrids between section Cyanococcus taxa and $V$. stamineum, were relatively easy to obtain, both at the diploid ( $V$. darrowii and diploid $V$. fuscatum $\times$ diploid $V$. stamineum) and at the tetraploid (highbush cultivars $\times$ tetraploid $V$. stamineum) levels (Table 2). The average of 0.25 to 0.29 good seeds per pollinated flower obtained in the diploid crosses (Table 2) is far below the 20 to 30 good seeds typical of homoploid crosses in section Cyanococcus, but is more than enough to generate large hybrid populations with relative ease.

With the tetraploid crosses, highbush cultivar $\times$ tetraploid $V$. stamineum gave an average of $0.68,0.77$, and 0.60 good seeds per pollinated flower in the three crossing seasons 2013, 2014, and 2015, with a total of 12,225 flowers pollinated. Again, these numbers are well below what would be expected from highbush $\times$ highbush crosses or from crosses between two $V$. stamineum clones, but they permit large populations of hybrids to be grown. Moreover, far more seedlings were obtained from these intersectional homoploid crosses than were obtained by crossing tetraploid (highbush cultivars) and diploid ( $V$. elliottii) members of the same section (Lyrene, 2014). This contrast shows that the triploid block is very strong in section Cyanococcus.

Lack of full compatibility in the intersectional crosses probably reflects the extent of evolutionary divergence between the two sections. Low pollen quality from the colchiploid $V$. stamineum plants seems not to have been a problem. Although autotetraploid plants obtained by treating diploid plants with colchicine often have reduced fertility compared with their diploid antecedents, in part because they produce frequent aneuploid gametes (Crane and Lawrence, 1952; Hagberg and Ellerstrom, 1959; Sanford, 1983), pollen tetrads from five of the tetraploid $V$. stamineum plants that were examined at $\times 250$, apart from its large size, seemed normal for $V$. stamineum. One clone was estimated to have $70 \%$ viable microspores and estimated microspore viability for the other four clones was $90 \%$ to $95 \%$. Similar high pollen quality was found in colchicineproduced tetraploid $V$. arboreum (Lyrene, 2011). At least two of the $V$. stamineum tetraploid clones used as parents were sectorial chimeras, with some branches producing conspicuously smaller flowers whose pollen was the normal size for diploids, but most of the pollen used in the crosses was from large flowers with large pollen. The tetraploid $V$. stamineum plants used as parents varied considerably in their ability to produce seeds when crossed onto highbush females (Table 1). At least two $V$. stamineum plants (not shown in Table 1) thought to be tetraploid based on pollen size gave few or no seeds when crossed onto highbush.

After reviewing many experiments in wide hybridization of plants, Darwin (1859) concluded that three measures of crossing success: the ease with which hybrids can be produced, the vigor of the resulting hybrids, and the fertility of the hybrids, are often not well correlated. This observation has been supported by many subsequent examples (Hadley and Openshaw, 1980; Stebbins, 1950). Some crosses that are very hard to make produce vigorous, fertile hybrids. Some crosses that are easy to make give weak or sterile hybrids. With the crosses reported here, the initial hybrids were easy to obtain, were low in vigor compared with their parents, but were surprisingly high in fertility, especially when used as female parents, both in intercrosses and in backcrosses to either parent.

After a comprehensive review of literature dealing with the rate of divergence of daughter taxa from a common ancestor, Levin $(2012,2013)$ concluded that hybrid sterility normally develops several million years before cross-incompatibility. In herbaceous taxa having the same ploidy level, hybrid sterility typically requires 4-5 million years to develop in subpopulations that have become isolated, and cross-incompatibility requires 8-10 million years. In trees, the waiting time for the development of sterility and cross-incompatibility are much longer, because the rate of molecular evolution in trees is roughly two to five times slower than in herbaceous plants (Levin, 2013). The extent of reduction in both cross-compatibility and hybrid fertility in the intersectional crosses reported here gives some indication of the amount of time that has passed since section Cyanococcus and section Polycodium diverged from their common ancestor.

The results of intersectional crosses of highbush cultivars with $V$. stamineum can be compared with previously reported crosses of highbush cultivars with $V$. arboreum (section Batodendron; Lyrene, 2011). In both cases, tetraploid forms of the diploid species were obtained using colchicine, and male fertility of these autotetraploids appeared to be only slightly reduced from that of the diploids based on examination of the pollen at $\times 250$. Intersectional hybrids with highbush cultivars were much easier to obtain using $V$. stamineum pollen ( 0.71 seeds per pollinated flower based on 12,225 flowers compared with 0.09 seeds per pollinated flower based on 17,968 flowers for $V$. arboreum). Both types of crosses produced a high percentage of very weak $\mathrm{F}_{1}$ plants, but a fraction of the $V$. arboreum $\mathrm{F}_{1}$ hybrids were highly vigorous whereas even the most vigorous $V$. stamineum $\mathrm{F}_{1}$ hybrids were less vigorous than either parent. With respect to $F_{1}$ male fertility, the two types of hybrids were quite similar. With $V$. arboreum, median microspore viability in $\mathrm{F}_{1}$ hybrids, estimated by microscopic examination, was $40 \%$ based on 91 hybrids; with $V$. stamineum the median was $30 \%$ based on 44 hybrids. With $V$. arboreum, 2658 highbush flowers pollinated with pollen from $F_{1}$ plants averaged 1.24 seeds per pollinated flower and with $V$. stamineum hybrids, 3250 highbush flower pollinated with pollen from $F_{1}$ plants gave an average of 1.47 seeds per pollinated flower. The reciprocal crosses, however, showed a marked contrast between $V$. arboreum and $V$. stamineum hybrids. Vaccinium arboreum $\mathrm{F}_{1}$ hybrids pollinated with highbush pollen gave an average of 0.81 seeds per pollinated flower (766 flowers), whereas $V$. stamineum $\mathrm{F}_{1}$ hybrids pollinated with highbush pollen averaged 7.00 seeds per pollinated flower (1102 flowers). Overall, in the comparisons, the $V$. arboreum hybrids seemed to be superior in vigor and the $V$. stamineum hybrids higher in fertility.

Hybridization with highbush blueberry, followed by backcrosses of the $F_{1}$ hybrids to $V$. stamineum, could be the first steps in domesticating $V$. stamineum as a new crop. Traits needed from highbush are easy propagation from softwood cuttings, elimination of objectionable bitter components from the fruit, and good retention of ripe berries on the plant. Ballington (personal communication) found that $\mathrm{F}_{1}$ hybrids between diploid $V$. corymbosum and $V$. stamineum were generally easy to root from leafy stem cuttings. Of the $14 \mathrm{~F}_{1}$ highbush $\times V$. stamineum hybrids tested in the present study, 8 rooted readily from softwood cuttings. The only hybrid for which no cuttings rooted behaved like $V$. stamineum, in that cuttings maintained their leaves well under mist but formed no roots. If backcrosses to $V$. stamineum produce some seedlings that root readily from cuttings, one major obstacle to domestication of $V$. stamineum will probably be easy to overcome. Bitterness was much reduced in the berries of the $F_{1}$ hybrids compared with the bitterness of $V$. stamineum berries. Some $\mathrm{F}_{1}$ hybrids retained their ripe berries well on the bush. For these three traits, the phenotypes of the hybrids gave encouraging indications that desirable highbush characters could be transferred into the $V$. stamineum gene pool.

The potential to obtain useful traits from $V$. stamineum to improve highbush blueberry cultivars also received encouragement from the phenotypes of the $F_{1}$ hybrids. Red 
pigmentation in the pulp of berries from one family shows that this character might be easily transferred. The hybrids showed the ability to flower on new spring growth, and their flowering racemes were very long and open. Vaccinium stamineum is a late-ripening species (Ballington et al., 1984a; Sharpe and Sherman, 1971) and could be used to breed highbush varieties that ripen later in the growing season. Whether hybrid plants will have better adaptation to upland soils remains to be seen. Recovery of commercially useful highbush cultivars after introgression of genes from $V$. stamineum should be made easier by the fact that the form of $V$. stamineum used in these crosses has several characteristics resembling highbush blueberry cultivars now being cultivated. The berries are large and juicy, with high Brix. Vaccinium stamineum resembles highbush blueberry in plant size, shape, and architecture. The flowers shed large amounts of pollen and are capable of high yield.

The low vigor of the tetraploid $F_{1}$ hybrids in the 2014 field nursery could portend problems in the backcross and intercross generations. However, some of the $\mathrm{F}_{1}$ hybrids that were dug for use in crosses grew with medium to high vigor in a soil-peat mix in $10 \mathrm{~L}$ pots in the greenhouse when mites were controlled. Vigorous plants are expected in the backcross generations, and a better understanding of their cultural requirements will probably enable identification of vigorous highbush- $V$. stamineum introgression lines.

One exciting aspect of any program of wide hybridization is the possibility of obtaining plants with surprising characteristics not seen in either parent. In segregating generations following wide hybridization, discovery of plants having novel characteristics that would never have been predicted from a study of the original parents of the cross is not uncommon in other taxa (Stebbins, 1950; Stevenson, 1965).

\section{Literature Cited}

Ashe, W.W. 1931. Polycodium. J. Elisha Mitchell Sci. Soc. 46:196-213.

Baker, P.C. 1970. A systematic study of the genus Vaccinium L. subgenus Polycodium (Raf.) Sleumer in the southeastern United States. Univ. North Carolina at Chapel Hill, NC, PhD Diss.

Ballinger, W.E., E.P. Maness, and J.R. Ballington. 1981. Anthocyanin and total flavonol content of Vaccinium stamineum L. fruit. Sci. Hort. 15:173-178.

Ballinger, W.E., E.P. Maness, and J.R. Ballington. 1982. Anthocyanins in ripe fruit of the sparkleberry, Vaccinium arboreum Marsh. Can. J. Plant Sci. 62:683-687.

Ballington, J.R. 1980. Crossability between subgenus Cyanococcus (Gray) Klotzsch and subgenus Polycodium (Raf.) Sleumer in Vaccinium. HortScience 15:419.

Ballington, J.R. 1995. The deerberry (Vaccinium stamineum L. Vaccinium section Polycodium (Raf.) Sleumer): A potential new small fruit crop, p. 21-28. In: R.E. Gough and R.F. Korcak (eds.). Blueberries: A century of research. Haworth Press, Inc., New York, NY.

Ballington, J.R. 2001. Collection, utilization, and preservation of genetic resources in Vaccinium. HortScience 36:213-220.

Ballington, J.R., W.E. Ballinger, C.M. Mainland, W.H. Swallow, E.P. Maness, G.J. Galletta, and L.J. Kushman. 1984a. Ripening period of Vaccinium species in southeastern North Carolina. J. Amer. Soc. Hort. Sci. 109:392-396.

Ballington, J.R., W.E. Ballinger, W.H. Swallow, G.J. Galletta, and L.J. Kushman. 1984b. Fruit quality characterization of 11 Vaccinium species. J. Amer. Soc. Hort. Sci. 109:684-689.

Ballington, J.R., W.E. Ballinger, E.P. Maness, and J.J. Luby. 1988. Anthocyanin, aglycone, and aglycone-sugar content of the fruits of five species of Vaccinium section Myrtillus. Can. J. Plant Sci. 68:241-246.

Brooks, S.J. and P.M. Lyrene. 1998. Derivatives of Vaccinium arboreum $\times$ Vaccinium section Cyanococcus. II. Fertility and fertility parameters. J. Amer. Soc. Hort. Sci. 123:997-1003.

Camp, W.H. 1945. The North American blueberries with notes on other groups of Vacciniaceae. Brittonia 5:203-275.

Chavez, D.J. and P.M. Lyrene. 2010. Hybridization of two diploid Vaccinium section Cyanococcus species with diploid Vaccinium arboreum in section Batodendron. Euphytica 171:263-272.

Coville, F.V. 1927. Blueberry chromosomes. Science 66:565-566.

Coville, F.V. 1937. Improving the wild blueberry, p. 559-574. In: Yearbook of the U.S. Department of Agriculture, 1937.

Crane, M.B. and W.J.C. Lawrence. 1952. The genetics of garden plants. 4th ed. Macmillan, London, United Kingdom.

Darrow, G.M. 1947. New varieties of blueberry, p. 300-303. In: USDA Yearbook of Agriculture 1943-1947.

Darrow, G.M. and W.H. Camp. 1945. Vaccinium hybrids and the development of new horticultural material. Bul. Torrey Bot. Club 72:1-21.

Darwin, C. 1859. On the origin of species. John Murray, Kent, London.

Galletta, G.J. 1975. Blueberries and cranberries, p. 154-196. In: J. Janick and J.N. Moore (eds.) Advances in fruit breeding. Purdue Univ. Press, West Lafayette, IN.

Hadley, H.H. and S.J. Openshaw. 1980. Interspecific and intergeneric hybridization, p. 133159. In: W.R. Fehr and H.H. Hadley (eds.). Hybridization of crop plants. Amer. Soc. Agron., Madison, WI.

Hagberg, A. and S. Ellerstrom. 1959. The competition between diploid, tetraploid, and aneuploid rye. Hereditas 45:369-416.

Levin, D.A. 2012. The long wait for hybrid sterility in flowering plants. New Phytol. 196:666-670.

Levin, D.A. 2013. The timetable for allopolyploidy in flowering plants. Ann. Bot. 112:1201-1208.

Longley, A.E. 1927. Chromosomes in Vaccinium. Science 66:566-568.

Luby, J.J., J.R. Ballington, A.D. Draper, K. Pliszka, and M.E. Austin. 1991. Genetic resources of temperate fruit and nut crops I. Blueberries and cranberries. Acta Hort. 290:393-458.

Lyrene, P.M. 1991. Fertile derivatives from sparkleberry $\times$ blueberry crosses. J. Amer. Soc. Hort. Sci. 116:899-902.

Lyrene, P.M. 2011. First report of Vaccinium arboreum hybrids with cultivated highbush blueberry. HortScience 46:563-566.
Lyrene, P.M. 2013. Fertility and other characteristics of $F_{1}$ and backcross 1 progeny from an intersectional blueberry cross (highbush cultivar $x$ Vaccinium arboreum) $\times$ highbush cultivar. HortScience 48:146-149.

Lyrene, P.M. 2014. The use of Vaccinium elliottii Chapmn. in breeding highbush blueberry. $<$ https:// rucore.libraries.rutgers.edu/rutgers-lib/45989>.

Lyrene, P.M. and J.R. Ballington. 1986. Wide hybridization in Vaccinium. HortScience 21:52-57.

Lyrene, P.M. and W.B. Sherman. 1983. Mitotic instability and $2 n$ gamete production in Vaccinium corymbosum $\times$ V. elliottii hybrids. J. Amer. Soc. Hort. Sci. 108:339-342.

McDaniel, S. 1962. A survey of the genus Vaccinium in Mississippi. Master's Thesis, Mississippi State Univ., MS.

Megalos, B.S. and J.R. Ballington. 1988. Unreduced pollen frequencies versus hybrid production in diploid-tetraploid Vaccinium crosses. Euphytica 39:271-278.

Ritchie, J.C. 1955a. A natural hybrid in Vaccinium I. The structure, performance and chorology of the cross Vaccinium intermedium Ruthe. New Phytol. 54:49-67.

Ritchie, J.C. 1955b. A natural hybrid in Vaccinium II. Genetic studies in Vaccinium intermedium Ruthe. New Phytol. 54:320-335.

Rousi, A. 1963. Hybridization between Vaccinium uliginosum and cultivated blueberry. Ann. Agr. Fenn. 2:12-18.

Sanford, J.C. 1983. Ploidy manipulations, p. 100123. In: J.N. Moore and J. Janick (eds.). Methods in fruit breeding. Purdue Univ. Press, West Lafayette, IN.

Sharpe, R.H. and W.B. Sherman. 1971. Breeding blueberries for low-chilling requirement. HortScience 6:145-147.

Stebbins, G.L. 1950. Variation and evolution in plants. Columbia Univ. Press, New York, NY.

Stevenson, J.C. 1965. Genetics and breeding of sugar cane. Longmans, London.

Steyermark, J.A. 1963. Flora of Missouri. Iowa State Univ. Press. Ames, IA.

Tsuda, H., H. Kunitake, M. Yamasaki, H. Komaatsu, and K. Yoshioka. 2013. Production of intersectional hybrids between colchicine-induced tetraploid Shashanbo (Vaccinium bracteatum) and highbush blueberry 'Spartan'. J. Amer. Soc. Hort. Sci. 138:317-324.

Uttal, L.J. 1987. The genus Vaccinium L. (Ericaceae) in Virginia. Castanea 52:231-255.

Vander Kloet, S.P. 1988. The genus Vaccinium in North America. Publ. 1828. Agriculture Canada.

Vander Kloet, S.P. 1997. The nature and variation of dichotomous characters in Vaccinium L. Amer. J. Bot. 84 No. 6 (Supplement to page 239) (abstr.).

Vorsa, N. and J.R. Ballington. 1991. Fertility of triploid highbush blueberry. J. Amer. Soc. Hort. Sci. 116:336-341.

Wang, S.Y. and J.R. Ballington. 2006. Free radical scavenging capacity and antioxidant enzyme activity in deerberry (Vaccinium stamineum L.). Food Science Technol. Today 73:13521361.

Zeldin, E.L. and B.H. McCown. 1997. Intersectional hybrids of lingonberry (Vaccinium vitisidaea, section vitis-idaea) and cranberry $(V$. macrocarpon, section oxycoccus) to Vaccinium reticulatum section macropelma. Acta Hort. 446:235-238. 